\title{
Networked Services of NIT libraries in India: A study
}

\author{
Y. Srinivasa Rao ${ }^{\mathrm{a}, *}$, B.K. Choudhury ${ }^{\mathrm{b}}$ \\ a National Institute of Technology, Rourkela, Orissa, India \\ b Sambalpur University, Sambalpur, Orissa, India
}

\section{A R T I C L E I N F O}

\section{Keywords:}

Networked Services (NSs)

Academic libraries

National Institute of Technology (NIT)

Library Services (LS)

\begin{abstract}
A B S T R A C T
The main purpose of the paper is to find out the provision of providing Networked Services (NSs) among National Institute of Technology (NIT) libraries in India. Methodology used for collecting data was questionnaire. The survey findings indicate that the majority of libraries prefer to provide communication network services (telephone, Internet, e-mail, facsimile etc), online journals (90\%), automated catalog system (85\%), multimedia databases (85\%) and support (70\%) services rather than the other services. Concerning the zone wise performance, south zone (80\%) libraries are more potential than the other zone libraries in providing NSs.
\end{abstract}

(c) 2010 Elsevier Ltd. All rights reserved.

\section{Introduction}

Digital revolution shapes libraries and their collections more visible, accessible and usable. The amount of digital information used in libraries is largely network-based. The carriage of information, transmission and retrieval of information are much different compared with traditional methods (Zhen, 1996). Proportionately, the use of libraries, users expectations and their information needs are high. Users continue in demanding timely information properly packed and delivered. They prefer to use and access networked information resources, rather than physical access (McClure, 2004). Therefore, the majority of academic libraries today create a network shelter in order to extract optimum use of their networked resources and services for meeting the preeminent academic needs.

Growing proportion of library services through network is enhancing the academic excellence in terms of teaching, learning and research. Library of an academic setting provides different kinds of NSs for different purposes. Basically, there are two types of NSs provided by the libraries: local and remote. Firstly, the local NSs are provided by local hosts (Abdullah \& Gay, 1994). Users may avail the facility of local NSs to access and use digital resources stored in the local computers and servers through a network platform. Local NSs link many workstations within a building to support access to transaction processing systems, such as a library management system (Rowley, 1996). Users are able to find and locate books and other materials through online catalog system. They can renew and reserve loan documents. They can also share, search and retrieve digital information resources starting from audio/visual system to network-based CD-ROM system. Besides users are trained and instructed to access and use electronic information resources, tools and techniques.

\footnotetext{
* Corresponding author.

E-mail addresses: ysraoo@gmail.com (Y. Srinivasa Rao), bkc_123@rediffmail.com (B.K. Choudhury).
} 
Secondly, the remote NSs are provided by remote hosts through Internet. Thus, the Internet plays an indispensable role for providing remote services. It has brought many new types of NSs. Historically there have been three primary services in use on the Internet: electronic mail, remote login, and file transfer (FTP) (Blumenfeld \& Droms, 1992). Generally, resources are stored in remote locations and user able to access those resources from their desktop from anywhere and from any location. These remote NSs are online databases, virtual reference, e-mail, document deliver, alerts, Really Simple Syndication (RSS) feeds, e-learning, e-publishing (e-news, news bulletins, blogs, wikis), etc. Multiple users keep continuous travel into library to access remote NSs without requiring their physical presence. Moreover, in an academic library setting, users get an opportunity to use and access both local and remote resources through availing NSs. During the process of providing NSs, there are many complicated interactions among technology, policy, organizations and people that require ongoing thought and clarification (McClure, Bertot, \& Hert, 1999). Further, lack of infrastructure facilities which include telecommunication networks, resources, funds and skilled manpower hampers the growth of libraries to meet the changing demands of the users (Shariful Islam \& Nazmul Islam, 2007). However, the libraries are constructive to perform NSs appropriately.

In this study, we briefly described NSs in order to have a clear understanding in their use among the NIT libraries in India. The NSs are not only attracting wider audience to access, search and retrieve resources but also reducing the cost, time and replication works in the library.

\subsection{Networked Services-Descriptions}

NSs are viewed as digital information services that users are able to access through network conduit. Shim et al. (2001) clearly indicate the definition of NSs and their use in the library settings. In this study, each service is described considering the NIT libraries across the country.

- Electronic Data Interchange (EDI) services

EDI is the process of obtaining and acquiring library materials that involve selection, order, receive and invoice actions.

- E-Catalog (E-CAT) services

E-CAT services facilitate in browsing, searching, finding and retrieving library documents such as books, journals, etc.

- E-Circulation (E-CIR) services

E-CIR services intend to check-out, check-in, renewal, reservation, etc. of library materials.

- Electronic/Virtual Reference (E/VR) services

E/VR services make real-time interactions between library staff and users in order to enquire and get reference materials through various modes such as e-mail, chatting, instant messaging, etc.

- Online services

Online services provide access to information resources (either licensed or non-licensed resources such as e-books, e-journals, abstract databases and open access journals) which are stored at remote locations.

- Multimedia Database (MD) services

MD services as medium of storage and retrieval, offer mixed media (CD-ROM and audio/video, etc) materials of user interest.

- Network Communication (NC) services

NC services use fast-paced communication tools (Internet, e-mail, telephone, facsimile, videotext/teletext, video and audio, etc) for information transfer and delivery.

- E-Current Awareness (E-CA) services

E-CA services (in the form of current contents, Selective Dissemination of Information (SDI), alert, new arrivals, newspaper-clipping) notify latest documents of various disciplines of user interest.

- Electronic and Web-based Document Delivery (E/WDD) services 
E/WDD services provide documents electronically in order to share resources held either by local or remote locations among internal and external users or libraries.

- Electronic Theses and Dissertations (ETD) services

ETD services disseminate newly created knowledge and intellectual research out of the institute or university.

- E-learning and Education (EL/E) services

$\mathrm{EL} / \mathrm{E}$ services transform knowledge and intend to educate users in use and access of course and learning materials.

- E-publishing (EP) services

EP services publicize and notify timely information through various platforms such as bulletin board, blog, wiki, etc.

- Support services

Support services are provided with an intension to train, instruct and assist users to access and use of library resources.

\section{National Institutes of Technology (NITs)-Background}

India is a huge country with a population of over one billion. In India, there are traditions in which education and learning are highly valued (Feith, 2008). India is yet to evolve a viable blueprint of higher educational system, though it exists for more than a century (Shivkumar, 2003). In fact, India is the largest higher education system in the world considering the number of institutions (Agarwal, 2006). During the second five year plan (1956-60) in India, a number of industrial projects were contemplated. To ensure enough supply of trained personnel to meet the demand for these projects, the decision was taken to start Regional Engineering Colleges (RECs), at the rate of one per each major state, which can churn out graduates with good engineering merit. Thus 17 RECs were established from 1959 onwards in each of the major states scattered throughout the country for regional development of technical manpower (All experts, 2009). These colleges were set up as joint and co-operative enterprise of the Central government and the State government concerned. Subsequently, on the recommendation of a High Powered Review Committee and an Empowered Committee, these colleges were granted the status of deemed University with professional management structure. In 2002, the Union Ministry of Human Resource Development, Government of India, decided to upgrade, in phases, all seventeen RECs as NITs. On 14th May 2003, all these seventeen institutions were taken over as fullyfunded institutions of the Central Government. These institutions are on the lines of the prestigious Indian Institutes of Technology (IITs) in terms of student quality, research and placements. Later, three Government engineering colleges (Patna, Raipur and Agartala) were added to NIT family. All the twenty institutes (Map 1) (Map, 2007) are benchmarking for technical education especially in the areas of engineering, science and technology. Recently, NIT Act-2007 has come into force with effect from August 15, 2007. As per the provision of the said Act, these institutions run on non-profitable basis and are declared as "institutions of national importance". All institutions have their own autonomy of drafting curriculum and functioning policies. They offer degree courses at various bachelors, masters and doctorate levels in various branches. Greater infrastructure facilities have been given to these institutions for development in teaching, learning, research and dissemination of information across the country.

\section{Review of literature}

Many studies explore on the topics of library-based network services. In global perspective, Yavarkovsky (1993) and Strempel (1996) investigated various studies on NSs in state libraries. Dempsey, Mumford, and Tuck (1994) and Dempsey (1993) introduced various technologies and standards which are considered to be important for emerging networked library services. Kistner (1992) and Geldenhuys (1995) described about the CD-ROM networked information services and end-user difficulties in accessing and using them. Owen and Wiercx (1996) proposed three basic models such as networked library model, co-operative network model and knowledge environment model for networked library services. Lakos (1997) discussed the issue of identifying library clients in the networked environment, investigated possible links between identification and service assessment. Gessesse (1997) conducted a pilot program on Internet-accessed current awareness services. Fletcher and Bertot (2000) and Razeq and Younis (2005) reported a new role for the networked library in providing online information services. Taha (2007) investigated that networked e-information services support the e-learning process at UAE University. Projects such as E-metrics and Measuring the Impact of Networked Electronic Services (MINES) for libraries etc are working on evaluation of networked information services.

In Indian context, various studies related to NSs have been carried out. Ganesan and Srinivasulu (2002) indicated the networkbased information services at IGM library, University of Hyderabad. It has been found that the NSs have become more useful, 


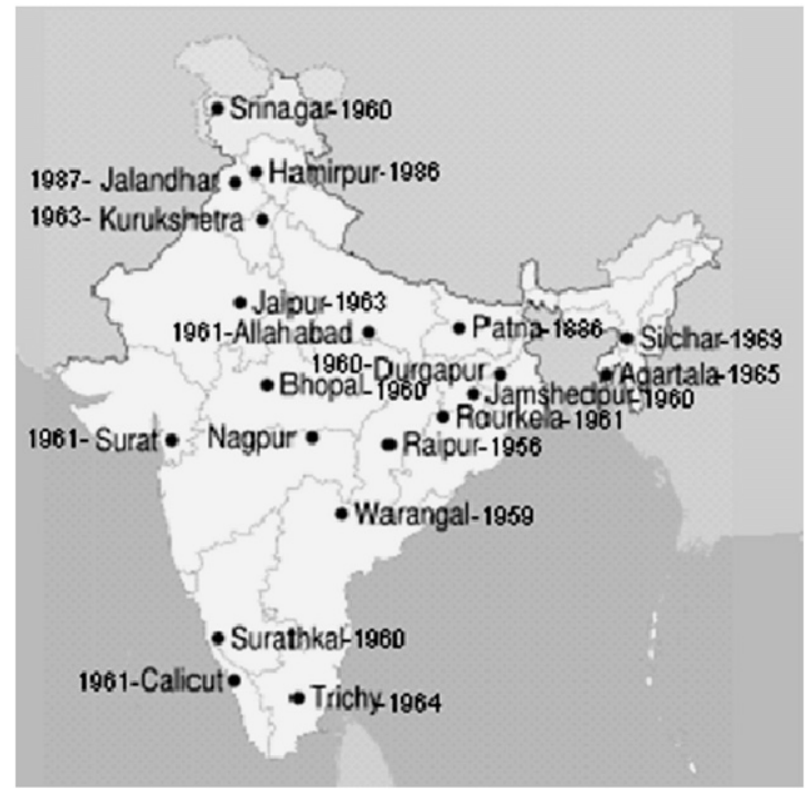

Map 1. Location of NITs in India.

simultaneously accessible and available in affordable costs. Vaishali and Dongre (2004) carried out a case study on electronic sources and services provided to users at Visvesvaraya National Institute of Technology Library, Nagpur. Vasishta (2007) undertook a case study on library automation and networked services at the technical deemed university libraries in North India. The survey findings conclude that most of the libraries are in transition stage. Kapoor and Goyal (2007) examined the functional comparison of web-based Online Public Access Catalogs (OPACs) in Indian academic libraries. Sivaraj, Esmail, and Kanakaraj

Table 1

Networked Services offered by the NIT libraries-zone wise.

\begin{tabular}{|c|c|c|c|c|c|c|c|c|c|c|}
\hline Sl. No. & Networked Services & & $\begin{array}{l}\text { North } \\
\text { (5) }\end{array}$ & $\begin{array}{l}\text { East } \\
(4)\end{array}$ & $\begin{array}{l}\text { NE } \\
(2)\end{array}$ & $\begin{array}{l}\text { South } \\
(4)\end{array}$ & $\begin{array}{l}\text { West } \\
(3)\end{array}$ & $\begin{array}{l}\text { Central } \\
(2)\end{array}$ & $\begin{array}{l}\text { Frequency } \\
(20)\end{array}$ & Percentage \\
\hline 1. & \multicolumn{2}{|c|}{ Electronic Data Interchange } & 2 & 2 & 1 & 4 & 2 & 0 & 11 & 55 \\
\hline \multirow[t]{2}{*}{2.} & \multirow[t]{2}{*}{ E-Catalog services } & OPAC & 5 & 3 & 1 & 4 & 3 & 1 & 17 & 85 \\
\hline & & Both (OPAC/webOPAC) & 2 & 2 & 0 & 4 & 2 & 0 & 10 & 50 \\
\hline 3. & E-Circulation services & Check-out, check-in, renewals & 2 & 2 & 1 & 4 & 2 & 0 & 11 & 55 \\
\hline 4. & Virtual reference service & Online/e-mail assistance & 1 & 1 & 0 & 4 & 2 & 0 & 8 & 40 \\
\hline \multirow[t]{4}{*}{5.} & \multirow[t]{4}{*}{ Online services } & E-books & 1 & 1 & 1 & 3 & 2 & 0 & 8 & 40 \\
\hline & & E-journals & 5 & 4 & 1 & 4 & 3 & 1 & 18 & 90 \\
\hline & & Abstracting databases & 1 & 2 & & 3 & 2 & 0 & 8 & 40 \\
\hline & & Open access journals (free) & 1 & 3 & 1 & 4 & 3 & 0 & 12 & 60 \\
\hline \multirow[t]{2}{*}{6.} & Multimedia database & Networked CD-ROM & 0 & 0 & 1 & 4 & 2 & 0 & 7 & 35 \\
\hline & Services & Audio and video cassettes & 5 & 3 & 1 & 4 & 3 & 1 & 17 & 85 \\
\hline \multirow[t]{6}{*}{7.} & \multirow{6}{*}{$\begin{array}{l}\text { Communication network } \\
\text { facilities }\end{array}$} & Internet & 5 & 4 & 2 & 4 & 3 & 1 & 19 & 95 \\
\hline & & E-mail services & 5 & 3 & 1 & 4 & 3 & 1 & 17 & 85 \\
\hline & & Telephone & 5 & 4 & 2 & 4 & 3 & 2 & 20 & 100 \\
\hline & & Facsimile (fax) & 0 & 2 & 0 & 1 & 1 & 1 & 5 & 25 \\
\hline & & Video and teleconferencing & 0 & 0 & 0 & 0 & 0 & 0 & 0 & 0 \\
\hline & & Videotext or teletext & 0 & 0 & 0 & 0 & 0 & 0 & 0 & 0 \\
\hline 8. & $\begin{array}{l}\text { E-current awareness } \\
\text { services }\end{array}$ & $\begin{array}{l}\text { Current contents/SDI/alert/new arrivals/newspaper } \\
\text { clipping }\end{array}$ & 0 & 2 & 1 & 4 & 2 & 0 & 9 & 45 \\
\hline 9. & \multicolumn{2}{|c|}{ Electronic/web-based document delivery services } & 1 & 2 & 0 & 2 & 1 & 1 & 7 & 35 \\
\hline 10. & \multicolumn{2}{|c|}{ Electronic theses and dissertations } & 0 & 1 & & 3 & 2 & 0 & 6 & 30 \\
\hline 11. & \multicolumn{2}{|c|}{ E-learning and education services } & 5 & 3 & 1 & 4 & 3 & 1 & 17 & 85 \\
\hline 12. & E-publishing services & E-library new bulletin/news letter & 0 & 1 & 0 & 2 & 0 & 0 & 3 & 15 \\
\hline \multirow[t]{3}{*}{13.} & \multirow[t]{3}{*}{ Support services } & User orientation/education/conventions & 4 & 3 & 1 & 4 & 2 & 0 & 14 & 70 \\
\hline & & Training user in the library & 4 & 2 & 0 & 3 & 2 & 0 & 11 & 55 \\
\hline & & Training staff & 4 & 3 & 1 & 3 & 2 & 0 & 13 & 65 \\
\hline
\end{tabular}


(2008) emphasized networking in the electronic transmission of data to make resource sharing viable at engineering college libraries in Tamil Nadu. Moghaddam and Talawar (2008) conducted a case study on the use of scholarly electronic journals at the Indian Institute of Science (IISc) and have pointed out that users show high interest in electronic journals that are accessible round the clock. Mahajan (2009) reported that a document delivery service is being provided to users on demand at Punjab University Library.

\section{Objectives of the study}

In Indian academic library environment, especially where the NITs are concern, there has been an increasing demand for NSs to access and publicize academic resources for meeting the academic needs. The main objectives in this study are as follows:

- To examine the provision of NSs among NIT libraries in India.

- To evaluate zone wise performance among NIT libraries in India concerning NSs.

\section{Methodology}

Methodology used for collecting data was questionnaire. The choice of selecting questionnaire method was survey-based. A questionnaire was designed in structural form. It has been framed into different sections which represent specific facets. The

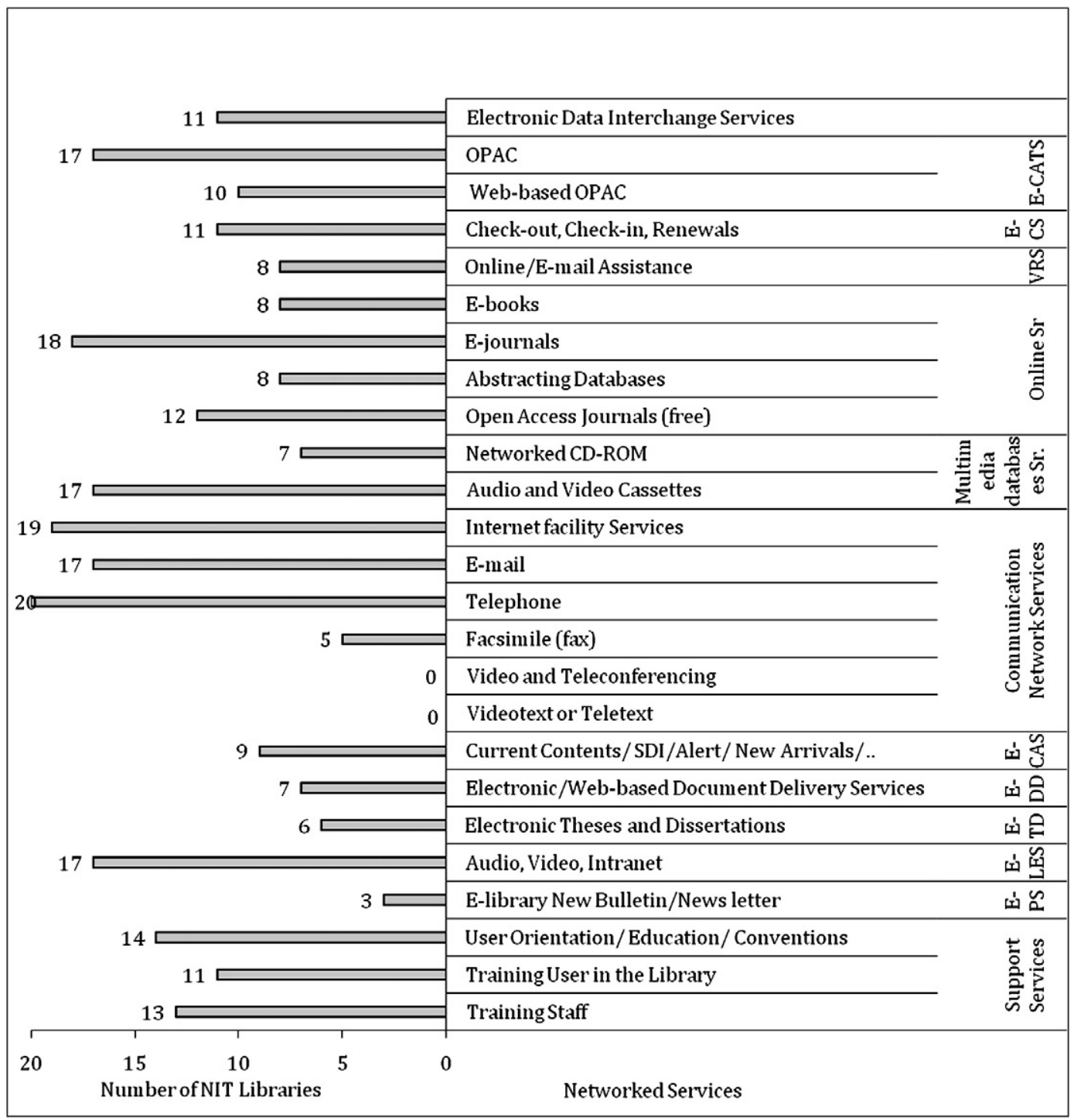

Fig. 1. Networked Services offered by the NIT libraries. 
Table 2

Networked Services among the NIT libraries-zone wise.

\begin{tabular}{|c|c|c|c|c|c|c|}
\hline Sl. no. & Zone & Name of the library & Score achieved & Total score achieved in zone wise & Total ideal score (25) in zone wise & Percentage \\
\hline 1 & \multirow[t]{5}{*}{ North } & MNNIT Allahabad & 11 & \multirow[t]{5}{*}{58} & \multirow[t]{5}{*}{125} & \multirow[t]{5}{*}{46} \\
\hline 2 & & NIT Hamirpur & 10 & & & \\
\hline 3 & & NIT Jalandhar & 12 & & & \\
\hline 4 & & NIT Kurukshetra & 14 & & & \\
\hline 5 & & NIT Srinagar & 11 & & & \\
\hline 6 & \multirow[t]{4}{*}{ East } & NIT Durgapur & 17 & \multirow[t]{4}{*}{53} & \multirow[t]{4}{*}{100} & \multirow[t]{4}{*}{53} \\
\hline 7 & & NIT Jamshedpur & 13 & & & \\
\hline 8 & & NIT Patna & 3 & & & \\
\hline 9 & & NIT Rourkela & 20 & & & \\
\hline 10 & \multirow[t]{2}{*}{ North east } & NIT Agartala & 2 & \multirow[t]{2}{*}{17} & \multirow[t]{2}{*}{50} & \multirow[t]{2}{*}{34} \\
\hline 11 & & NIT Silchar & 15 & & & \\
\hline 12 & \multirow[t]{4}{*}{ South } & NIT Calicut & 23 & \multirow[t]{4}{*}{80} & \multirow[t]{4}{*}{100} & \multirow[t]{4}{*}{80} \\
\hline 13 & & NIT Surathkal & 19 & & & \\
\hline 14 & & NIT Tiruchirapalli & 21 & & & \\
\hline 15 & & NIT Warangal & 17 & & & \\
\hline 16 & \multirow[t]{3}{*}{ West } & MNIT Jaipur & 15 & \multirow[t]{3}{*}{54} & \multirow[t]{3}{*}{75} & \multirow[t]{3}{*}{72} \\
\hline 17 & & VNIT Nagpur & 19 & & & \\
\hline 18 & & SVNIT Surat & 20 & & & \\
\hline 19 & \multirow[t]{2}{*}{ Central } & MANIT Bhopal & 9 & \multirow[t]{2}{*}{10} & \multirow[t]{2}{*}{50} & \multirow[t]{2}{*}{20} \\
\hline 20 & & NIT Raipur & 1 & & & \\
\hline
\end{tabular}

sample size was twenty, as they are limited in number. The questionnaire was served to administrators of the library (librarians) among NITs. A reminder was sent to those librarians who failed to respond in time. Finally, all responses were received. The data (Annexure) that are considered important for this study were quantified using numerical scales (i.e. $0-1$ ) for the purpose of analysis.

\section{Scope and limitations}

The present study is confined only to twenty NIT libraries in India, concerning NSs offered by them. Data received from the respondents were authenticated and assumed to be factual. User interview/opinions and their degree of satisfaction through user survey would have added more value to the present study.

\section{Findings}

The data that are considered for this study were described and analyzed based on the objectives. Moreover, the NSs are arranged zone wise such as north, east, north east (NE), south, west and central in order to determine the performance among them.

Table 1 shows the following findings:

- Forty-five percent of respondents indicate that the EDI processes in the libraries are at primitive stage of automating the acquisition processes such as selection, order, receive and invoice actions using library software packages.

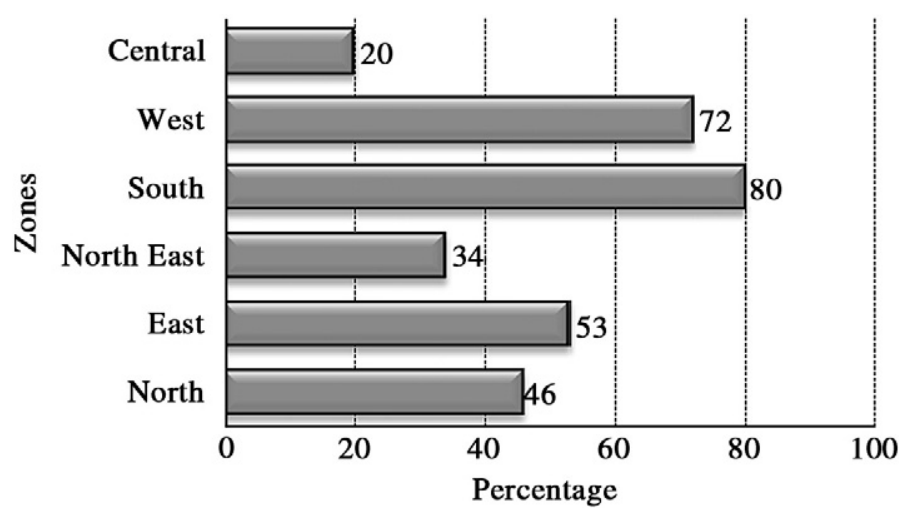

Fig. 2. Networked Services-zone wise. 
- Majority of the libraries (85\%) indicated that they provide E-CAT services. Out of $85 \%, 35 \%$ of libraries automate their Online Public Access Catalog (OPAC) system, whereas 50\% of libraries have both OPAC and web-based OPAC system. Fifteen percent of libraries still maintain the manual system.

- Fifty-five percent of the libraries reportedly said that they got their circulation system automated whereas $45 \%$ of libraries use the manual processing system yet.

- Forty-five percent of libraries state, they interact with users through e-mail, chatting and instant messaging while eleven (55\%) libraries are yet to offer E/VR services.

- Forty percent of libraries mentioned that they provide e-book services. Majority of libraries (90\%) provide e-journal services. forty percent of libraries indicated that, they use abstracting databases. Sixty percent of libraries, opting for open access journals (free) services.

- Eighty-five percent of respondents indicate that they have the facility of accessing CD-ROM and audio/video services. In which only $35 \%$ of libraries have the provision of network-based CD-ROM services.

- Almost all library respondents indicate that they have the facility of telephone and Internet, but $85 \%$ of libraries use e-mail. Five libraries have facsimile (fax) facility services in the library. No NIT library across the country provides videotext/teletext and video/teleconferencing facilities.

- About $45 \%$ of libraries reported that they provide e-current awareness services.

- Seven (35\%) libraries reported that they provide electronic as well as web-based document delivery services whereas $65 \%$ of libraries are in the progress.

- Majority of respondents (70\%) indicate that they do not have the facility of electronic theses and dissertations services, compared to six (30\%) libraries which offer this facility.

- Most of the libraries (85\%) reported that they have the facility of providing e-learning and education services through both CDROM and audio/video.

- Majority of the libraries (85\%) are not aware of e-publishing services. Two libraries (Calicut and Tiruchirapalli) indicate that they provide e-library news bulletin and news letter services. NIT Rourkela is the only library maintaining a 'Blog' and a Wiki for publishing or posting e-documents.

- Seventy percent of library respondents reported that they conduct user orientation, user education and user convention programs.

- Fifty-five percent of libraries reportedly said that they provide training to users in the library.

- Sixty-five percent of libraries offer training to staff as well.

An amount of NSs offered by the NIT Libraries is illustrated in Fig. 1.

\section{Networked Services-Zone wise performance}

The study further moves zone wise to prioritize them based on the service availability at NIT libraries. The zones are north, east, north east, south, west and central. The zones are considered based on the regions across the country to explore the average regional performance rather individual with respect to NSs.

Table 2 projects that the south zone (80\%) is much ahead of other zones, followed by the west zone with a percentage of 72 . The east zone (53\%) is moderate in providing such services followed by the north zone with $46 \%$. The north east (34\%) and the central zones (20\%) are way behind in this context of catering these services. The percentage is shown in Fig. 2.

\section{Conclusion}

The trend of NSs is evolving in a more global way. Majority of academic institutions use NSs in order to access and use library resources stored in both local and remote locations. From the findings it is observed that all NIT libraries have basic network infrastructure facilities to access communication network services such as telephone, Internet, e-mail, etc., in which the majority of them are more constant about online journal databases, online catalogs and CD-ROM/audio/video course materials accessibility. However, with respect to EDI, automated circulation system and support services (orientation programs and training users and staff) many NIT libraries are at average level of performance in providing them. The rest of the services rendered by NIT libraries are at the below average performance. In fact, no NIT library across the country provides videotext/teletext and video/ teleconferencing facilities.

Based on the observations, the south zone libraries have more potential in providing NSs followed by west. The east zone libraries perform moderately. The other zone (north, north east and central) libraries are at immature stage in providing NSs. Possibilities to have high and low performance among the zones in providing NSs are educational and management culture, acquisition of resources, funds and efficient manpower, etc. In spite of the above findings, it is concluded that many libraries are in the developing stage in provision of NSs except a few libraries. Of course the policy construction could be possible at various levels in order to create access to NSs among NIT libraries. However, with limited infrastructure facilities, the NITs are able to manage their libraries and provide services effectively. Future research is required to identify the problems to use and access of NSs with respect to Indian libraries irrespective of its genre. 
Annexure

Networked Services offered by the NIT libraries in zone wise.

\begin{tabular}{|c|c|c|c|c|c|c|c|c|c|c|c|c|c|}
\hline \multirow[t]{3}{*}{ Sl. no } & \multirow[t]{3}{*}{ Zones } & \multirow[t]{3}{*}{ Library } & \multirow{3}{*}{$\begin{array}{l}\text { EDI } \\
\text { services } \\
(1)\end{array}$} & \multicolumn{2}{|c|}{$\begin{array}{l}\text { E-Catalog } \\
\text { services }\end{array}$} & \multirow{3}{*}{$\begin{array}{l}\text { E-Circulation } \\
\text { services } \\
\\
(1)\end{array}$} & \multirow{3}{*}{$\begin{array}{l}\begin{array}{l}\text { Virtual } \\
\text { reference } \\
\text { service }\end{array} \\
(1)\end{array}$} & \multicolumn{4}{|c|}{ Online services } & \multicolumn{2}{|c|}{$\begin{array}{l}\text { Multimedia databases } \\
\text { services }\end{array}$} \\
\hline & & & & \multirow{2}{*}{$\begin{array}{l}\mathrm{OPAC} \\
\overline{(1)}\end{array}$} & \multirow{2}{*}{$\begin{array}{l}\text { OPAC/web } \\
\text { OPAC } \\
(1)\end{array}$} & & & \multirow{2}{*}{$\frac{\text { E-books }}{(1)}$} & \multirow{2}{*}{$\frac{\text { E-journals }}{(1)}$} & \multirow{2}{*}{$\begin{array}{l}\text { Abs. } \\
(1)\end{array}$} & \multirow{2}{*}{$\frac{\begin{array}{l}\mathrm{OAJ} \\
\text { (free) }\end{array}}{(1)}$} & \multirow{2}{*}{$\begin{array}{l}\text { Networked } \\
\text { CD-ROM } \\
(1)\end{array}$} & \multirow{2}{*}{$\begin{array}{l}\begin{array}{l}\text { Audio and } \\
\text { video }\end{array} \\
(1)\end{array}$} \\
\hline & & & & & & & & & & & & & \\
\hline 1 & North & MNNIT Allahabad & $\sqrt{ }$ & $\sqrt{ }$ & $\sqrt{ }$ & $\sqrt{ }$ & $\mathrm{x}$ & $\mathrm{x}$ & $\sqrt{ }$ & $\mathrm{x}$ & $\sqrt{ }$ & $\mathrm{x}$ & $\sqrt{ }$ \\
\hline 2 & & NIT Hamirpur & $\mathrm{x}$ & $\sqrt{ }$ & $\mathrm{x}$ & $\mathrm{x}$ & $\mathrm{x}$ & $\mathrm{x}$ & $\sqrt{ }$ & $\mathrm{x}$ & $\mathrm{x}$ & $\mathrm{x}$ & $\sqrt{ }$ \\
\hline 3 & & NIT Jalandhar & $\mathrm{x}$ & $\sqrt{ }$ & $\mathrm{x}$ & $\mathrm{x}$ & $\sqrt{ }$ & $\mathrm{x}$ & $\sqrt{ }$ & $\mathrm{x}$ & $\mathrm{x}$ & $\mathrm{x}$ & $\sqrt{ }$ \\
\hline 4 & & NIT Kurukshetra & $\sqrt{ }$ & $\sqrt{ }$ & $\sqrt{ }$ & $\sqrt{ }$ & $\mathrm{x}$ & $\sqrt{ }$ & $\sqrt{ }$ & $\mathrm{x}$ & $\mathrm{x}$ & $\mathrm{x}$ & $\sqrt{ }$ \\
\hline 5 & & NIT Srinagar & $\mathrm{x}$ & $\sqrt{ }$ & $\mathrm{x}$ & $\mathrm{x}$ & $\mathrm{x}$ & $\mathrm{x}$ & $\sqrt{ }$ & $\sqrt{ }$ & $\mathrm{x}$ & $\mathrm{x}$ & $\sqrt{ }$ \\
\hline 6 & East & NIT Durgapur & $\sqrt{ }$ & $\sqrt{ }$ & $\sqrt{ }$ & $\sqrt{ }$ & $\mathrm{x}$ & $\sqrt{ }$ & $\sqrt{ }$ & $\mathrm{x}$ & $\sqrt{ }$ & $\mathrm{x}$ & $\sqrt{ }$ \\
\hline 7 & & NIT Jamshedpur & $\mathrm{x}$ & $\sqrt{ }$ & $\mathrm{x}$ & $\mathrm{x}$ & $\mathrm{x}$ & $\mathrm{x}$ & $\sqrt{ }$ & $\sqrt{ }$ & $\sqrt{ }$ & $\mathrm{x}$ & $\sqrt{ }$ \\
\hline 8 & & NIT Patna & $\mathrm{x}$ & $\mathrm{x}$ & $\mathrm{x}$ & $\mathrm{x}$ & $\mathrm{x}$ & $\mathrm{x}$ & $\sqrt{ }$ & $\mathrm{x}$ & $\mathrm{x}$ & $\mathrm{x}$ & $\mathrm{x}$ \\
\hline 9 & & NIT Rourkela & $\sqrt{ }$ & $\sqrt{ }$ & $\sqrt{ }$ & $\sqrt{ }$ & $\sqrt{ }$ & $\mathrm{x}$ & $\sqrt{ }$ & $\sqrt{ }$ & $\sqrt{ }$ & $\mathrm{x}$ & $\sqrt{ }$ \\
\hline 10 & North east & NIT Agartala & $\mathrm{x}$ & $\mathrm{x}$ & $\mathrm{x}$ & $\mathrm{x}$ & $\mathrm{x}$ & $\mathrm{x}$ & $\mathrm{x}$ & $\mathrm{x}$ & $\mathrm{x}$ & $\mathrm{x}$ & $\mathrm{x}$ \\
\hline 11 & & NIT Silchar & $\sqrt{ }$ & $\sqrt{ }$ & $\mathrm{x}$ & $\sqrt{ }$ & $\mathrm{x}$ & $\sqrt{ }$ & $\sqrt{ }$ & $\mathrm{x}$ & $\sqrt{ }$ & $\sqrt{ }$ & $\sqrt{ }$ \\
\hline 12 & South & NIT Calicut & $\sqrt{ }$ & $\sqrt{ }$ & $\sqrt{ }$ & $\sqrt{ }$ & $\sqrt{ }$ & $\sqrt{ }$ & $\sqrt{ }$ & $\sqrt{ }$ & $\sqrt{ }$ & $\sqrt{ }$ & $\sqrt{ }$ \\
\hline 13 & & NIT Surathkal & $\sqrt{ }$ & $\sqrt{ }$ & $\sqrt{ }$ & $\sqrt{ }$ & $\sqrt{ }$ & $\mathrm{x}$ & $\sqrt{ }$ & $\sqrt{ }$ & $\sqrt{ }$ & $\sqrt{ }$ & $\sqrt{ }$ \\
\hline 14 & & NIT Tiruchirapalli & $\sqrt{ }$ & $\sqrt{ }$ & $\sqrt{ }$ & $\sqrt{ }$ & $\sqrt{ }$ & $\sqrt{ }$ & $\sqrt{ }$ & $\sqrt{ }$ & $\sqrt{ }$ & $\sqrt{ }$ & $\sqrt{ }$ \\
\hline 15 & & NIT Warangal & $\sqrt{ }$ & $\sqrt{ }$ & $\sqrt{ }$ & $\sqrt{ }$ & $\sqrt{ }$ & $\sqrt{ }$ & $\sqrt{ }$ & $\mathrm{x}$ & $\sqrt{ }$ & $\sqrt{ }$ & $\sqrt{ }$ \\
\hline 16 & West & MNIT Jaipur & $\mathrm{x}$ & $\sqrt{ }$ & $\mathrm{x}$ & $\mathrm{x}$ & $\sqrt{ }$ & $\mathrm{x}$ & $\sqrt{ }$ & $\mathrm{x}$ & $\sqrt{ }$ & $\sqrt{ }$ & $\sqrt{ }$ \\
\hline 17 & & VNIT Nagpur & $\sqrt{ }$ & $\sqrt{ }$ & $\sqrt{ }$ & $\sqrt{ }$ & $\mathrm{x}$ & $\sqrt{ }$ & $\sqrt{ }$ & $\sqrt{ }$ & $\sqrt{ }$ & $\sqrt{ }$ & $\sqrt{ }$ \\
\hline 18 & & SVNIT Surat & $\sqrt{ }$ & $\sqrt{ }$ & $\sqrt{ }$ & $\sqrt{ }$ & $\sqrt{ }$ & $\sqrt{ }$ & $\sqrt{ }$ & $\sqrt{ }$ & $\sqrt{ }$ & $\mathrm{x}$ & $\sqrt{ }$ \\
\hline 19 & Central & MANIT Bhopal & $\mathrm{x}$ & $\sqrt{ }$ & $\mathrm{x}$ & $\mathrm{x}$ & $\mathrm{x}$ & $\mathrm{x}$ & $\sqrt{ }$ & $\mathrm{x}$ & $\mathrm{x}$ & $\mathrm{x}$ & $\sqrt{ }$ \\
\hline 20 & & NIT Raipur & $\mathrm{x}$ & $\mathrm{x}$ & $\mathrm{x}$ & $\mathrm{x}$ & $\mathrm{x}$ & $\mathrm{x}$ & $\mathrm{x}$ & $\mathrm{x}$ & $\mathrm{x}$ & $\mathrm{x}$ & $\mathrm{x}$ \\
\hline
\end{tabular}




\begin{tabular}{|c|c|c|c|c|c|c|c|c|c|c|c|c|c|}
\hline \multicolumn{6}{|c|}{ Communication network services } & \multirow{3}{*}{$\begin{array}{l}\text { E-CAS } \\
\frac{(1)}{}\end{array}$} & \multirow{3}{*}{$\begin{array}{l}\text { E/WDDS } \\
(1)\end{array}$} & \multirow{3}{*}{$\begin{array}{l}\text { ETD } \\
\frac{1}{(1)}\end{array}$} & \multirow{3}{*}{$\begin{array}{l}\text { ELES } \\
\frac{}{(1)}\end{array}$} & \multirow{3}{*}{$\begin{array}{l}\text { EPS } \\
\frac{(1)}{-}\end{array}$} & \multicolumn{3}{|c|}{ Support services } \\
\hline Internet & E-mail & Telephone & $\begin{array}{l}\text { Facsimile } \\
\text { (fax) }\end{array}$ & $\begin{array}{l}\text { Video and } \\
\text { teleconferencing }\end{array}$ & $\begin{array}{l}\text { Videotext } \\
\text { or teletext }\end{array}$ & & & & & & $\begin{array}{l}\text { User } \\
\text { ori/edu/ } \\
\text { conventions }\end{array}$ & $\begin{array}{l}\text { Training } \\
\text { user in } \\
\text { the library }\end{array}$ & $\begin{array}{l}\text { Training } \\
\text { staff }\end{array}$ \\
\hline (1) & (1) & (1) & (1) & (1) & (1) & & & & & & (1) & (1) & (1) \\
\hline$\sqrt{ }$ & $\sqrt{ }$ & $\sqrt{ }$ & $\mathrm{x}$ & $\mathrm{x}$ & $\mathrm{x}$ & $\mathrm{x}$ & $\mathrm{x}$ & $\mathrm{x}$ & $\sqrt{ }$ & $\mathrm{x}$ & $\mathrm{x}$ & $\mathrm{x}$ & $\mathrm{x}$ \\
\hline$\sqrt{ }$ & $\sqrt{ }$ & $\sqrt{ }$ & $\mathrm{x}$ & $\mathrm{x}$ & $\mathrm{x}$ & $\mathrm{x}$ & $\mathrm{x}$ & $\mathrm{x}$ & $\sqrt{ }$ & $\mathrm{x}$ & $\sqrt{ }$ & $\sqrt{ }$ & $\sqrt{ }$ \\
\hline$\sqrt{ }$ & $\sqrt{ }$ & $\sqrt{ }$ & $\mathrm{x}$ & $\mathrm{x}$ & $\mathrm{x}$ & $\mathrm{x}$ & $\sqrt{ }$ & $\mathrm{x}$ & $\sqrt{ }$ & $\mathrm{x}$ & $\sqrt{ }$ & $\sqrt{ }$ & $\sqrt{ }$ \\
\hline$\sqrt{ }$ & $\sqrt{ }$ & $\sqrt{ }$ & $\mathrm{x}$ & $\mathrm{x}$ & $\mathrm{x}$ & $\mathrm{x}$ & $\mathrm{x}$ & $\mathrm{x}$ & $\sqrt{ }$ & $\mathrm{x}$ & $\sqrt{ }$ & $\sqrt{ }$ & $\sqrt{ }$ \\
\hline$\sqrt{ }$ & $\sqrt{ }$ & $\sqrt{ }$ & $\mathrm{x}$ & $\mathrm{x}$ & $\mathrm{x}$ & $\mathrm{x}$ & $\mathrm{x}$ & $\mathrm{x}$ & $\sqrt{ }$ & $\mathrm{x}$ & $\sqrt{ }$ & $\sqrt{ }$ & $\sqrt{ }$ \\
\hline$\sqrt{ }$ & $\sqrt{ }$ & $\sqrt{ }$ & $\sqrt{ }$ & $\mathrm{x}$ & $\mathrm{x}$ & $\mathrm{x}$ & $\sqrt{ }$ & $\mathrm{x}$ & $\sqrt{ }$ & $\mathrm{x}$ & $\sqrt{ }$ & $\sqrt{ }$ & $\sqrt{ }$ \\
\hline$\sqrt{ }$ & $\sqrt{ }$ & $\sqrt{ }$ & $\sqrt{ }$ & $\mathrm{x}$ & $\mathrm{x}$ & $\sqrt{ }$ & $\mathrm{x}$ & $\mathrm{x}$ & $\sqrt{ }$ & $\mathrm{x}$ & $\sqrt{ }$ & $\mathrm{x}$ & $\sqrt{ }$ \\
\hline$\sqrt{ }$ & $\mathrm{x}$ & $\sqrt{ }$ & $\mathrm{x}$ & $\mathrm{x}$ & $\mathrm{x}$ & $\mathrm{x}$ & $\mathrm{x}$ & $\mathrm{x}$ & $\mathrm{x}$ & $\mathrm{x}$ & $\mathrm{x}$ & $\mathrm{x}$ & $\mathrm{x}$ \\
\hline$\sqrt{ }$ & $\sqrt{ }$ & $\sqrt{ }$ & $\mathrm{x}$ & $\mathrm{x}$ & $\mathrm{x}$ & $\sqrt{ }$ & $\sqrt{ }$ & $\sqrt{ }$ & $\sqrt{ }$ & $\sqrt{ }$ & $\sqrt{ }$ & $\sqrt{ }$ & $\sqrt{ }$ \\
\hline$\sqrt{ }$ & $\mathrm{x}$ & $\sqrt{ }$ & $\mathrm{x}$ & $\mathrm{x}$ & $\mathrm{x}$ & $\mathrm{x}$ & $\mathrm{x}$ & $\mathrm{x}$ & $\mathrm{x}$ & $\mathrm{x}$ & $\mathrm{x}$ & $\mathrm{x}$ & $\mathrm{x}$ \\
\hline$\sqrt{ }$ & $\sqrt{ }$ & $\sqrt{ }$ & $\mathrm{x}$ & $\mathrm{x}$ & $\mathrm{x}$ & $\sqrt{ }$ & $\mathrm{x}$ & $\mathrm{x}$ & $\sqrt{ }$ & $\mathrm{x}$ & $\sqrt{ }$ & $\mathrm{x}$ & $\sqrt{ }$ \\
\hline$\sqrt{ }$ & $\sqrt{ }$ & $\sqrt{ }$ & $\sqrt{ }$ & $\mathrm{x}$ & $\mathrm{x}$ & $\sqrt{ }$ & $\sqrt{ }$ & $\sqrt{ }$ & $\sqrt{ }$ & $\sqrt{ }$ & $\sqrt{ }$ & $\sqrt{ }$ & $\sqrt{ }$ \\
\hline$\sqrt{ }$ & $\sqrt{ }$ & $\sqrt{ }$ & $\mathrm{x}$ & $\mathrm{x}$ & $\mathrm{x}$ & $\sqrt{ }$ & $x$ & $\sqrt{ }$ & $\sqrt{ }$ & $x$ & $\sqrt{ }$ & $\sqrt{ }$ & $\sqrt{ }$ \\
\hline$\sqrt{ }$ & $\sqrt{ }$ & $\sqrt{ }$ & $x$ & $x$ & $x$ & $\sqrt{ }$ & $\sqrt{ }$ & $x$ & $\sqrt{ }$ & $\sqrt{ }$ & $\sqrt{ }$ & $\sqrt{ }$ & $\sqrt{ }$ \\
\hline$\sqrt{ }$ & $\sqrt{ }$ & $\sqrt{ }$ & $\mathrm{x}$ & $x$ & $\mathrm{x}$ & $\sqrt{ }$ & $\mathrm{x}$ & $\sqrt{ }$ & $\sqrt{ }$ & $\mathrm{x}$ & $\sqrt{ }$ & $\mathrm{x}$ & $x$ \\
\hline$\sqrt{ }$ & $\sqrt{ }$ & $\sqrt{ }$ & $x$ & $x$ & $\mathrm{x}$ & $\sqrt{ }$ & $\mathrm{x}$ & $\sqrt{ }$ & $\sqrt{ }$ & $\mathrm{x}$ & $\sqrt{ }$ & $\sqrt{ }$ & $\sqrt{ }$ \\
\hline$\sqrt{ }$ & $\sqrt{ }$ & $\sqrt{ }$ & $x$ & $x$ & $x$ & $\sqrt{ }$ & $\sqrt{ }$ & $\sqrt{ }$ & $\sqrt{ }$ & $\mathrm{x}$ & $\mathrm{x}$ & $\sqrt{ }$ & $\sqrt{ }$ \\
\hline$\sqrt{ }$ & $\sqrt{ }$ & $\sqrt{ }$ & $\sqrt{ }$ & $x$ & $\mathrm{x}$ & $\mathrm{x}$ & $\mathrm{x}$ & $x$ & $\sqrt{ }$ & $\mathrm{x}$ & $\sqrt{ }$ & $\mathrm{x}$ & $x$ \\
\hline$\sqrt{ }$ & $\sqrt{ }$ & $\sqrt{ }$ & $\sqrt{ }$ & $\mathrm{x}$ & $x$ & $\mathrm{x}$ & $\sqrt{ }$ & $x$ & $\sqrt{ }$ & $x$ & $x$ & $\mathrm{x}$ & $\mathrm{x}$ \\
\hline $\mathrm{x}$ & $\mathrm{x}$ & $\sqrt{ }$ & $x$ & $x$ & $\mathrm{x}$ & $x$ & $\mathrm{x}$ & $x$ & $x$ & $x$ & $\mathrm{x}$ & $x$ & $x$ \\
\hline
\end{tabular}




\section{References}

Abdullah, Abdul Hanan, \& Gay, Btiau (1994). Implementing an interface to networked services. ACM, 25-33.

Agarwal, Pawan (2006). Higher education in India: The need for changeIndian Council for Research on International Economic Relations (ICRIER) Working Paper, 180. (pp. 1-182).

All experts. Encyclopedia. Retrieved May 10, 2009 from http://en.allexperts.com/e/n/na/national_institutes_of_technology.htm.

Blumenfeld, Mitchell, \& Droms, Ralph (1992). A uniform interface to networked library services. ACM, 608-613.

Dempsey, L., Mumford, A., \& Tuck, B. (1994). Towards the virtual library: Standards for networked library services. Axis, 1, 21-29.

Dempsey, Lorcan (1993). Networks, standards and end-user information services. Vine, 93, 3-11.

Feith, David (2008). India's higher education sector in the twenty-first century-A growing market, and the need for greater international engagement. 17th Biennial Conference of the Asian Studies Association of Australia in Melbourne 1-3 July 2008.

Fletcher, Patricia Diamond, \& Bertot, J. C. (Eds.). (2000). World libraries on the information superhighway: Preparing for the challenges of the new millennium. Penn: Idea Group Publishing.

Ganesan, P., \& Srinivasulu, P. (2002). Network based information services-A glance at IGM Library, University of Hyderabad.

Geldenhuys, A. (1995). CDROM networking in an academic library-two case studies: Trial, tribulation and success at the University of Pretoria. Electronic Library, $13,371-376$.

Gessesse, K. (1997). Internet-accessed CAS at the Rodgers library: A pilot programme. Library Management, 18, 380-386.

Kapoor, Kanta, \& Goyal, O. P. (2007). Web-based OPACs in Indian academic libraries: A functional comparison. Program: Electronic Library and information systems, 41, 291-309.

Kistner, J. C. (1992). Integrating CD-ROM into networked information services. Online Information 92. 16th International Online Information Meeting Proceedings (pp. 301-312). Oxford: learned Inf.

Lakos, A. (1997). Identifying and assessing library clients in a networked environment: Issues and possibilities. Proceedings of the 2nd Northumbria International Conference on Performance Measurement in Libraries and Information Services, Newcastle upon Tyne (pp. 287-293). UK: Information North.

Mahajan, Preeti (2009). Information-seeking behavior: A study of Punjab University, India. Library Philosophy and Practice. available at: http://unllib.unl.edu/LPP/ mahajan4.htm accessed 30 March 2009.

Map. Retrieved August 12, 2007 from http://en.wikipedia.org/wiki/File:NIT_Locations.svg.

McClure, C. R. (2004). Challenges and strategies for evaluating networked information services: Introduction. The Library Quarterly, 74, 399-402.

McClure, C. R., Bertot, J. C., \& Hert, Carol A. (1999). Expanding our knowledge of evaluating networked information services and resources: Prelude to the mid-year meeting. Bulletin of the American Society for Information Science, 25, 7-29.

Moghaddam, G. G., \& Talawar, V. G. (2008). The use of scholarly electronic journals at the Indian Institute of Science: A Case Study in India. Interlending and Document Supply, 36, 15-29.

Owen, J. S. M., \& Wiercx, A. (1996). Knowledge models for Networked Library Services. Luxembourg: European Commission.

Razeq, Abdul, \& Younis, Mustafa (2005). Local online information systems in Jordanian university libraries. Online Information Review, $29,54-74$.

Rowley, J. (1996). Basics of the information systems. London: Library Association Publishing.

Shariful Islam, Md., \& Nazmul Islam, Md. (2007). Use of ICT in libraries: An empirical study of selected libraries in Bangladesh. Library Philosophy and Practice. available at: http://unllib.unl.edu/LPP/shariful.htm accessed 23 August 2007.

Shim, Wonsik Jeff, McClure, C. R., \& Bertot, J. C. (2001). Measures and statistics for research library networked services: ARL E-Metrics Phase II Report. available at: http://www.arl.org/newsltr/219/emetrics.html accessed 01 November 2007.

Shivkumar, V. (2003, Jul 08). Encountering emerging challenges. Hindu, Retrieved November 10, 2007 from. http://www.hinduonnet.com/thehindu/edu/2003/ 07/08/stories/2003070800110200.htm.

Sivaraj, S., Esmail, Mohammed, \& Kanakaraj, M. (2008). Bridging the information divide among engineering college libraries in Tamil Nadu, India: A Network Design. Library Philosophy and Practice. available at: http://unllib.unl.edu/LPP/sivaraj.htm accessed 28 March 2008.

Strempel, G. (1996). Networking information services in South Australia. Australian Library Review, 13, 277-280.

Taha, Ahmed (2007). Networked e-information services to support the e-learning process at UAE university. Electronic Library, 25, 349-362.

Vaishali, C. Gudadhe, \& Dongre, Sandesh M. (2004). An analytical study of electronic sources and services provided to users with special reference to research scholars of Visvesvaraya National Institute of Technology library, Nagpur. Proceedings of 2nd International CALIBER-2004, February 11-13, 2004, New Delhi (pp. 100-105). Gujurat: INFLIBNET.

Vasishta, S. (2007). Library automation and networked services: A case study at the technical deemed university libraries in North India. IASLIC Bulletin, 52, $120-126$.

Yavarkovsky, J. (1993). The New York State library: A vision for networked services. Journal of Library Administration, 19, $133-146$.

Zhen, W. (1996). Network in the library information services. Proceedings of the 17th Annual IATUL Conference. Networks, Networking and Implications for Digital Libraries, 24-28 June 1996. Irvine. 